\title{
Sovereign Debt: A Modern Greek Tragedy
}

\author{
Fernando M. Martin and Christopher J. Waller
}

\begin{abstract}
The authors of this article provide a general introduction to the concept of sovereign debt-including the seductive nature of borrowing and the strategies associated with default-before analyzing the current debt crises in Europe. They focus on Greece's current woes but also discuss Portugal, Ireland, Italy, and Spain. The authors also discuss the environment in the United States, which has a high debt burden of its own, and present fiscal choices for policymakers and taxpayers. (JEL E52, E61, E62, H63)
\end{abstract}

Federal Reserve Bank of St. Louis Review, September/October 2012, 94(5), pp. 321-39.

$\mathbf{F}$ or the second time in five years, the world faces a financial crisis that threatens the health of the global economy. The first crisis, in 2007-08, was driven by excessive mortgage debt owed by households. The current crisis is driven by excessive government debt owed by entire countries. The common factor driving both of these crises is the fear that debts will not be repaid. While this is a constant concern with individual households, it is almost unimaginable that highly developed economies with democratic governments would default on their debt. Yet that is the harsh reality we face as Portugal, Ireland, Italy, Greece, and Spain-the so-called PIIGS countries-struggle to get their debt under control. And it is not only the southern European countries that are in trouble-the United States and France had their credit ratings downgraded in 2011 because of fears of long-run insolvency.

At moments like these, the public begins to ask questions about national debt:

- Why do nations borrow?

- When does the level of debt become a burden?

- What happens if a nation defaults on its debt?

- How did Europe get itself into this situation, and how can it get out?

- Is the United States in equally serious trouble because of its debt?

This article addresses these questions and provides some insight as to what may happen in the future.

Fernando M. Martin is a senior economist and Christopher J. Waller is a senior vice president and the director of research at the Federal Reserve Bank of St. Louis. This article is a version of the 2011 Federal Reserve Bank of St. Louis Annual Report, "Sovereign Debt: A Modern Greek Tragedy" (www.stlouisfed.org/publications/ar/2011/pdf/2011-annual-report.pdf). The authors thank Lowell Rickets for assistance in preparing the charts.

(c) 2012, The Federal Reserve Bank of St. Louis. The views expressed in this article are those of the author(s) and do not necessarily reflect the views of the Federal Reserve System, the Board of Governors, or the regional Federal Reserve Banks. Articles may be reprinted, reproduced, published, distributed, displayed, and transmitted in their entirety if copyright notice, author name(s), and full citation are included. Abstracts, synopses, and other derivative works may be made only with prior written permission of the Federal Reserve Bank of St. Louis. 


\section{THE FUNCTION OF NATIONAL DEBT}

When governments spend more than they receive in tax revenue during a given period, they must finance the shortfall by borrowing. The current shortfall is called the deficit. If a country generates more tax revenue than the government spends, it runs a surplus, which pays off existing debt. Thus, the national debt is the sum of the current and all past deficits/surpluses. For example, the 2011 U.S. federal deficit was $\$ 1.3$ trillion, while the national debt was about $\$ 10$ trillion. 1 This $\$ 10$ trillion debt is the net accumulation of all spending shortfalls back to the founding of the country. $\underline{2}$

But why would a country choose to spend more than it earns in tax revenue? For many of the same reasons individuals borrow: to consume more goods today at the cost of consuming less tomorrow.

Why would a government choose to have more consumption today? Historically, the answer has been wars. Wars are expensive and require the government to acquire large quantities of goods and services immediately. Governments could finance this need by dramatically raising taxes temporarily. However, it is actually better to borrow the resources and slowly repay the debt over time with permanently higher future taxes. This is referred to as "tax smoothing," a concept articulated by Robert Barro, an economist at Harvard University, in an influential 1979 paper. The concept underlying tax smoothing is similar to that of a mortgage-homeowners borrow a lot of money to buy a house now and slowly pay it off over time.

In addition to wars, government borrowing has been used to finance civil works, such as the interstate highway system. Modern governments have also borrowed to finance less tangible items, such as education, pensions, and medical care.

By borrowing today, governments are implying that they will raise future taxes to pay off their debts. A key issue is how burdensome these future taxes will be. As a rule of thumb, economists look at the ratio of the national debt to national income as a measure of the country's debt burden. The idea is to see how hard it would be to pay off all of the nation's debt with one year of national income (i.e., gross domestic product [GDP]). Note that this is a very conservative measure of a debt burden; it considers using only one year's income rather than a stream of future income to repay the debt, and it ignores the wealth of the nation. Notice that by this measure, the debt burden can be reduced by paying off debt or by the economy growing faster than debt.

\section{ROLLING OVER DEBT AND DEFAULT}

Since the national debt is the accumulation of all past deficits, does this mean that debt issued to finance, say, the Civil War, has never been repaid? No. That specific debt was repaid by running a surplus and rolling over the debt. "Rolling over the debt" means paying off old debt by issuing new debt (akin to paying off your Visa card with your MasterCard). Nearly all nations in the world have outstanding sovereign debt, and they typically roll over the debt when it comes due.

Government debt is issued at different maturities, which determines when the debt is to be repaid. Governments typically borrow funds with maturity dates as short as 3 months and as 


\section{Figure 1}

\section{U.S. Treasury Security Yield Curve}

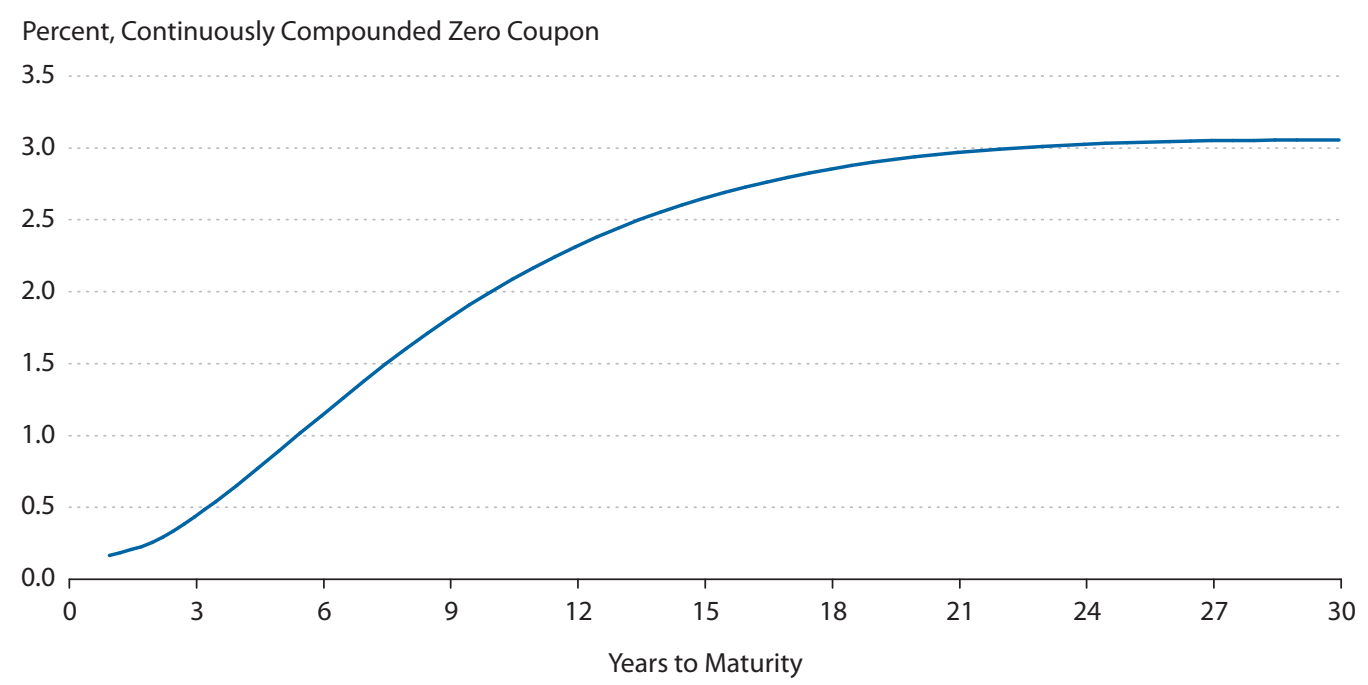

NOTE: Values shown correspond to bond yields as of the end of December 2011.

SOURCE: Federal Reserve Board/Haver Analytics.

long as 30 years. The interest rate paid by the government depends on the term to maturity when the debt is issued. The relationship between the interest rate paid and the maturity of the debt is called the term structure of interest rates-or, more succinctly, the yield curve. Figure 1 plots the yield curve for U.S. debt.

The yield curve in Figure 1 has the typical shape: upward sloping, meaning that the longer the time to repayment, the higher is the interest rate. Simply put, it is much cheaper to borrow for a short period of time than to borrow for a long period of time. Consequently, governments have an incentive to issue debt with a short maturity. However, this requires them to roll over their debt more often. As a result, governments face a trade-off-borrow more cheaply but run the risk that the debt will not be rolled over. Thus, governments typically issue debt at a variety of maturities.

Creditors are willing to roll over the debt if they believe they will be repaid in the future. If they fear this will not happen, then they will ask for immediate repayment of the debt or demand a very high interest rate to compensate them for the risk of default. In either case, the government would need to increase tax revenue or reduce spending to obtain the resources needed to repay the debt and the interest. But the government cannot be forced to repay its debt-it may choose to simply default. $\frac{3}{-}$

While the idea that an advanced country such as the United States would default on its debt seems crazy, historically it has been quite common for sovereigns to default on their debts. Economists Carmen Reinhart at the Peterson Institute for International Economics and Kenneth Rogoff at Harvard University document the history of sovereign debt in their 2009 book This Time Is Different: Eight Centuries of Financial Folly. 


\section{Martin and Waller}

Between 1300 and 1799, now-rich European countries such as Austria, England, France, Germany (Prussia), Portugal, and Spain all defaulted at least once on their sovereign debt. France and Spain led the pack, with eight and six default episodes each. The nineteenth century witnessed a surge of sovereign debt defaults and rescheduling in Africa, Europe, and Latin America; Spain alone defaulted eight times.

Sometimes, countries default on their external creditors. Other times, governments default on their own citizens. In today's complex and interconnected world economy, which traits make us classify debt as internal or external? Consider the following relevant criteria. First, a government may issue debt in its own currency or debt denominated/indexed in some foreign currency. Second, debt may be held by residents or nonresidents. Third, debt may be adjudicated by local authorities or international institutions. A country's debt likely will have both internal and external components because of the degree of integration of today's capital markets.

Governments typically favor issuing debt in their own currency since this allows them to print money to repay it, if necessary. Generating revenue from newly printed money (a process known as seigniorage) to repay debt has been a recurrent practice for centuries and typically generates high inflation rates for a period of time. The financing of debt through inflation constitutes a form of (partial) default because the currency used to repay the debt decreases in value as prices increase. For example, the burden of the debt accumulated by the government during World War II was significantly reduced by the large postwar inflation of 1946-48. Lee Ohanian (1998), an economist at the University of California, Los Angeles, estimated that the reduction of the real value of debt resulting from the increase in prices was equivalent to a repudiation of debt worth 40 percent of gross national product. However, printing money to repay debt carries a cost-inflation. A country can overuse seigniorage and create very high inflation rates, even hyperinflation. Some of the most notorious episodes of inflation in the past 100 years include Germany and Hungary in the early 1920s, Bolivia in 1984-85, Argentina in 1989-90, and Zimbabwe in 2008.

Governments may alternatively issue debt denominated in foreign currency. This helps governments with a record of high inflation to increase their credibility with creditors, as the option to use seigniorage to repay the debt is no longer available. In fact, a country's credibility may be so low that it has no option but to issue debt in a more stable foreign currency. However, a government may reach a point where it is no longer willing to tax its citizens to acquire the foreign currency necessary to meet its obligations, choosing instead to default. A good example is the Argentine sovereign debt default and restructuring in 2002.

Who holds the debt-residents or nonresidents-has an impact on the incentives to default. Clearly, it is politically more difficult for elected officials to default on residents because residents can oust those representatives from office. However, defaulting on external creditors is not a "free lunch." Countries can be barred from international capital markets until a satisfactory debt restructuring agreement has been reached. As with individuals, a country's bad credit history implies higher financing rates and lower borrowing ceilings.

Finally, where payment disputes are resolved is of paramount importance. A defaulting government is likely to have much more influence over local courts than foreign courts. Reinhart and Rogoff (2009) argue that the only absolute criterion when classifying debt as internal is that it be adjudicated by domestic authorities. 
So, why and when do countries default? Often, default is driven by the markets' unwillingness to roll over existing debt or their willingness to do so only at a prohibitively high cost. This may occur because creditors believe the debt of a nation is high enough that the government may be unable to levy enough resources to repay its debt.

Thus, the higher the debt burden, the more likely a country is to default on its debt. However, the debt burden is not always a good predictor of default. For example, Brazil and Mexico defaulted in the early 1980 s when their debt-to-GDP ratios were only 50 percent, whereas Japan has not defaulted in the post-World War II period, even though its debt burden has exceeded 100 percent since the mid-1990s and is currently 200 percent.

This suggests that creditors often refuse to roll over debt because they believe governments are unwilling - instead of unable - to tax citizens enough to meet debt obligations. In other words, creditors fear a country does not have the political will to raise taxes or cut spending to get its fiscal house in order. $\underline{4}$

The sheer magnitude of the debt burden is, therefore, insufficient to predict default; other complementary indicators, such as sovereign ratings by international credit-rating agencies (Standard \&Poor's, Moody's, and so on) and the debt-to-exports ratio, need to be taken into account.

Although defaulting on sovereign debt is an age-old phenomenon, there has not been an outright default by a developed nation since 1946, which is why the current financial crisis in Europe has caused such a stir. But European countries have been in debt for decades and with relatively high debt-to-GDP ratios. So why has this crisis surfaced now?

\section{THE EUROPEAN UNION AND THE EURO}

After two world wars fought on its own soil within a generation, Europe embarked on a strategy to ensure that war would never come to Europe again. A key element of that strategy was an integrated European economy and potentially a single currency. The belief was that the greater the economic integration of Europe, the less likely countries would be to go to war again. Thus, with the signing of the Treaty of Rome in 1957, the European Union (EU) was created, and Europe began the process of creating - if not politically, at least economically-the United States of Europe. Over the decades since, tariffs and capital controls were eliminated, free mobility of labor across borders was allowed, and substantial fiscal transfers flowed from the north to the south for economic development. Then, in 1992, the Maastricht treaty was signed, which paved the way for the Economic and Monetary Union (EMU) and a single currency-the euro. The euro would be managed by a pan-European institution known as the European Central Bank (ECB).

The economic performance of countries in the EU varied greatly. In order to ensure a smooth transition to a single currency, these differences had to be reduced. To speed the convergence of economic performance across EU members, three criteria were established for a country to join the monetary union. First, a country's long-term nominal interest rate had to be within 2 percentage points of the average rate of the three EU members with the lowest rates. Second, the inflation rate had to be within 1.5 percentage points of the average of the three EU members with the lowest inflation rates. Finally, a country had to join the exchange rate mecha- 
Martin and Waller

\section{Figure 2}

\section{A. Long-Term Interest Rates for the Original Euro Zone Members except Portugal, Ireland, Italy, and Spain}

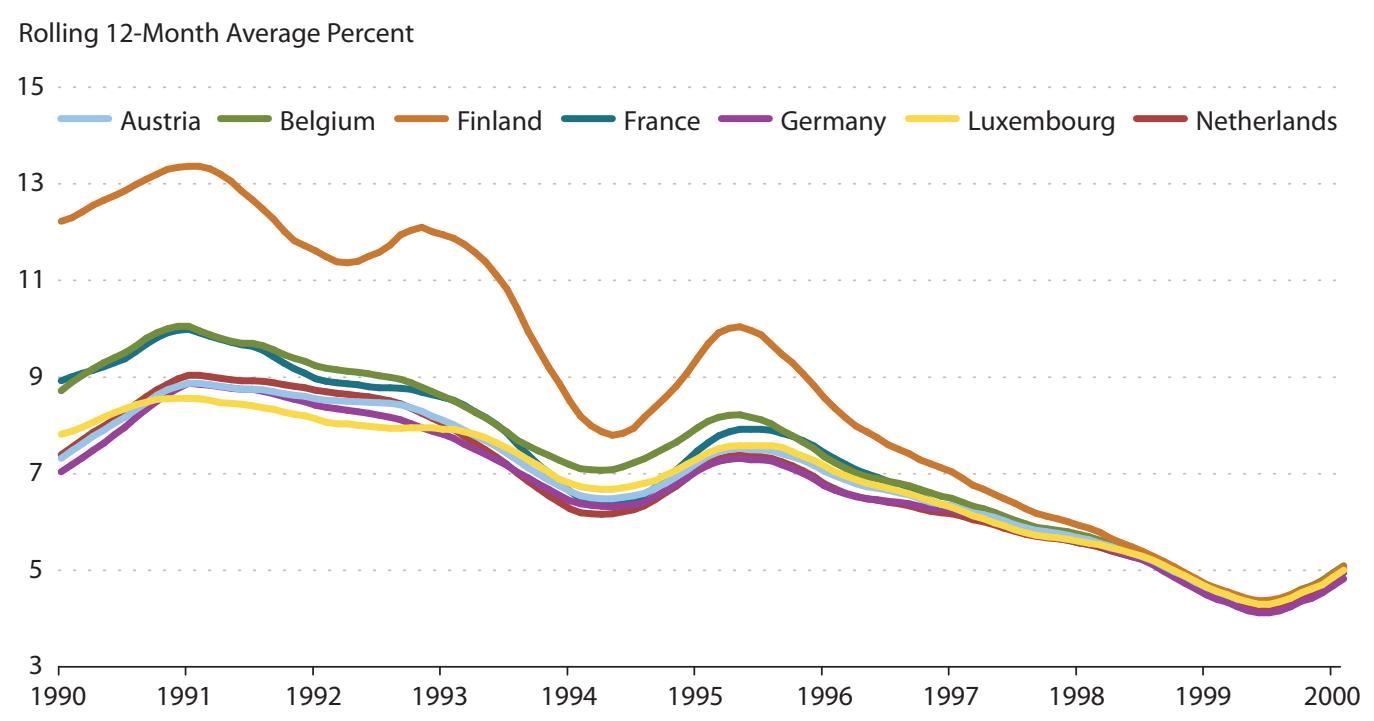

\section{B. Long-Term Interest Rates for Portugal, Ireland, Italy, Greece, and Spain (PIIGS)}

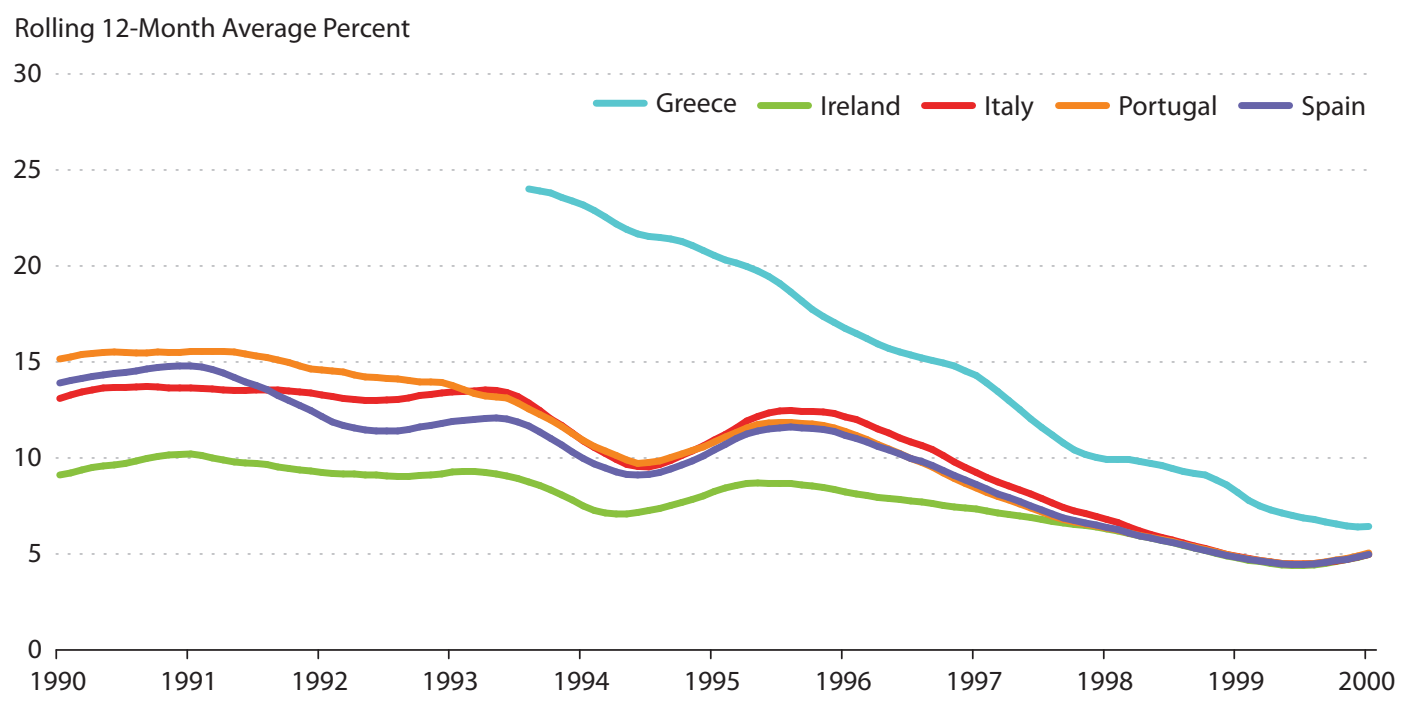

SOURCE: DG II/Statistical Office European Communities/Haver Analytics. 


\section{Figure 3}

\section{A. Annual Inflation}

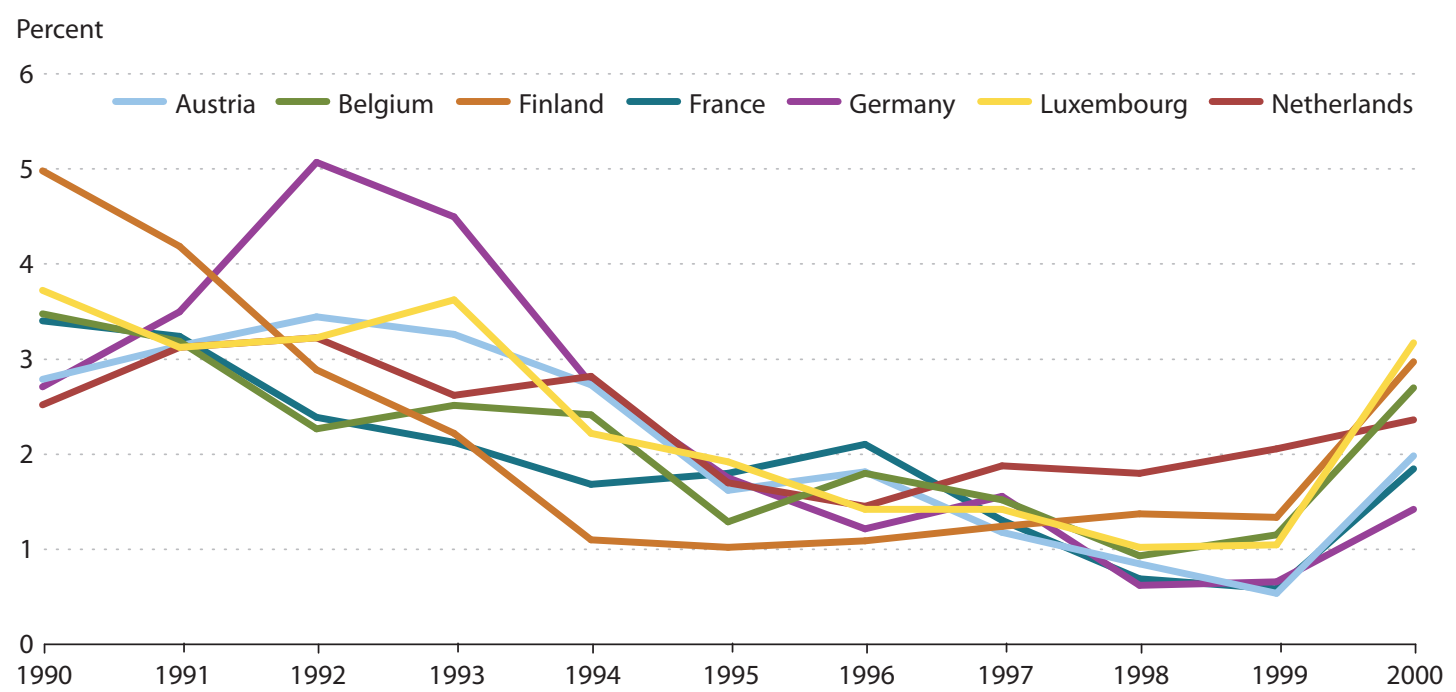

\section{B. Annual Inflation (PIIGS)}

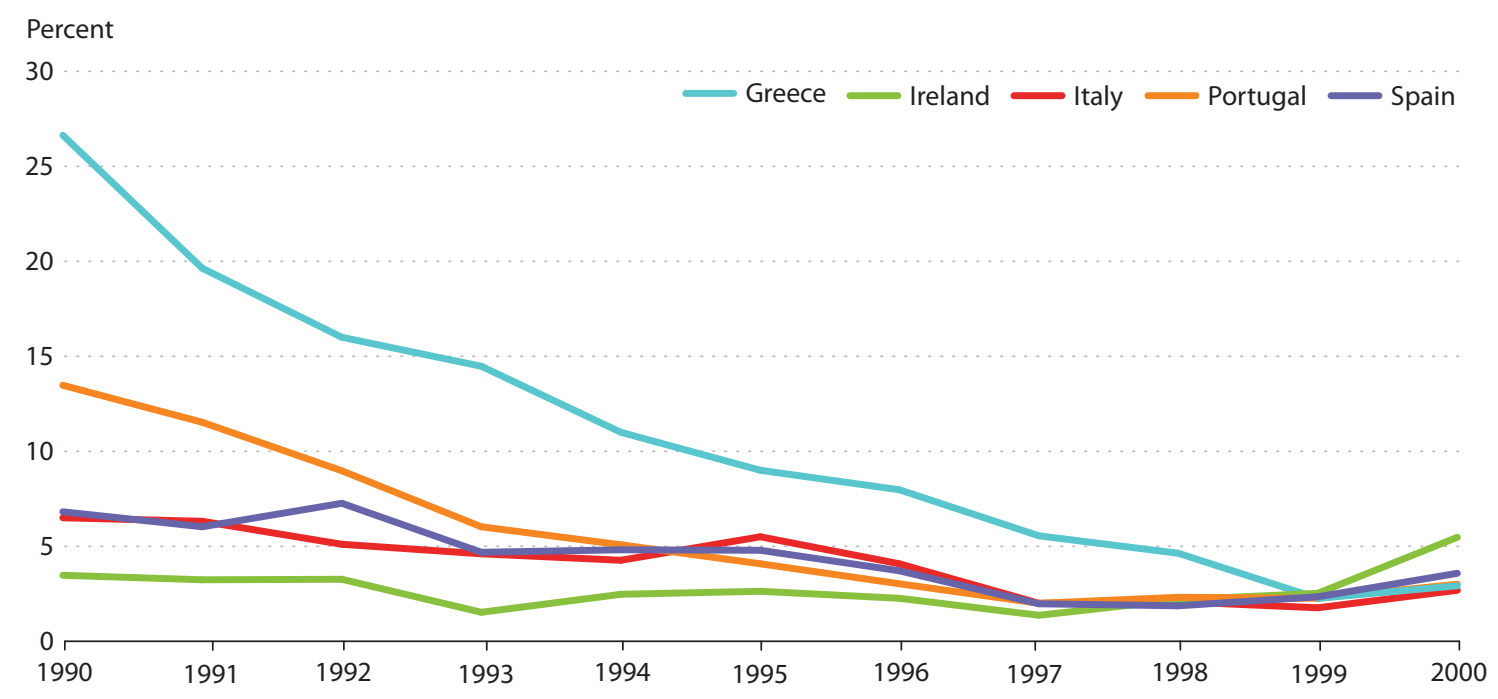

SOURCE: International Monetary Fund, World Economic Outlook Database, April 2012. 


\section{Martin and Waller}

nism, which required maintaining the currency exchange rate within a narrow band for two consecutive years without significant devaluation.

These criteria imposed economic discipline at the central banks of prospective members of the EMU. Most of the countries that adopted the euro succeeded in meeting these requirements, as shown in Figures 2 and 3. Nevertheless, there was great concern that if governments did not get their fiscal houses in order, the new ECB could be pressured to print money to finance spending by those governments.

Because it had experienced hyperinflation from seigniorage creation, Germany was adamant that certain fiscal criteria had to be met to avoid this fate for all of Europe. Consequently, in 1997, the Stability and Growth Pact was signed. This pact added two criteria for prospective members of the EMU. First, they were required to keep the ratio of their deficits as a fraction of GDP to 3 percent or less. Second, they were required to keep the ratio of their gross government debt to GDP at or below 60 percent. The idea was that the Stability and Growth Pact would impose economic discipline on governments of prospective members. This goal had varying degrees of success, as shown in Figures 4 and 5.

Countries had to meet a total of five economic criteria to join the EMU. Unfortunately, all of these criteria were to be met only before a country joined the EMU-once a country joined, the requirements of fiscal discipline vanished.

A constant concern in the 1990s for those studying the EU process was how to handle a secession or ouster of a country from the EMU or EU. Many argued that the Maastricht treaty needed to lay out contingency plans for such an event. However, for political reasons, this was not discussed. Making plans for the breakup of a union before it even started seemed ludicrous. In short, you can't talk about divorce on your wedding night! Alas, as often happens in marriage, this lack of planning would come back to haunt the EU.

\section{THE START OF THE EMU AND GREECE'S SHAKY ENTRY}

The euro was officially launched in 1999 as a unit of account, with actual notes and coins being issued in 2002. There were 11 original members of the EMU; member countries form the euro area, which is more commonly referred to as the euro zone. Greece was not a member even though it wanted entry. It was initially denied entry to the EMU in 1998 but won entry in 2000 and joined the euro zone in 2001.

Greece was denied entry in 1998 because it had met none of the economic criteria specified in the Maastricht treaty or the Stability and Growth Pact. In 1997, Greece had high inflation (5.4 percent) and very high long-term interest rates ( 9.9 percent), it did not participate in the exchange rate mechanism, its deficit-to-GDP ratio was 6 percent, and its debt-to-GDP ratio was

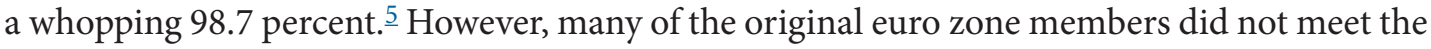
fiscal criteria either, as shown in Figures 4 and 5.

Nevertheless, several potential euro zone members were moving in the right direction. Italy, for example, had lowered its deficit-to-GDP ratio from 11 percent in 1990 to only about 1 percent in 2000, while lowering its debt-to-GDP ratio from a peak of 121 percent in 1994 to under 110 percent in 2000. Belgium, despite having the highest debt-to-GDP ratio in Europe, had lowered it from 126 percent in 1990 to 108 percent in 2000. Most surprising, the "Celtic Tiger," Ireland, 


\section{Figure 4}

\section{A. Government Deficit-to-GDP Ratio}

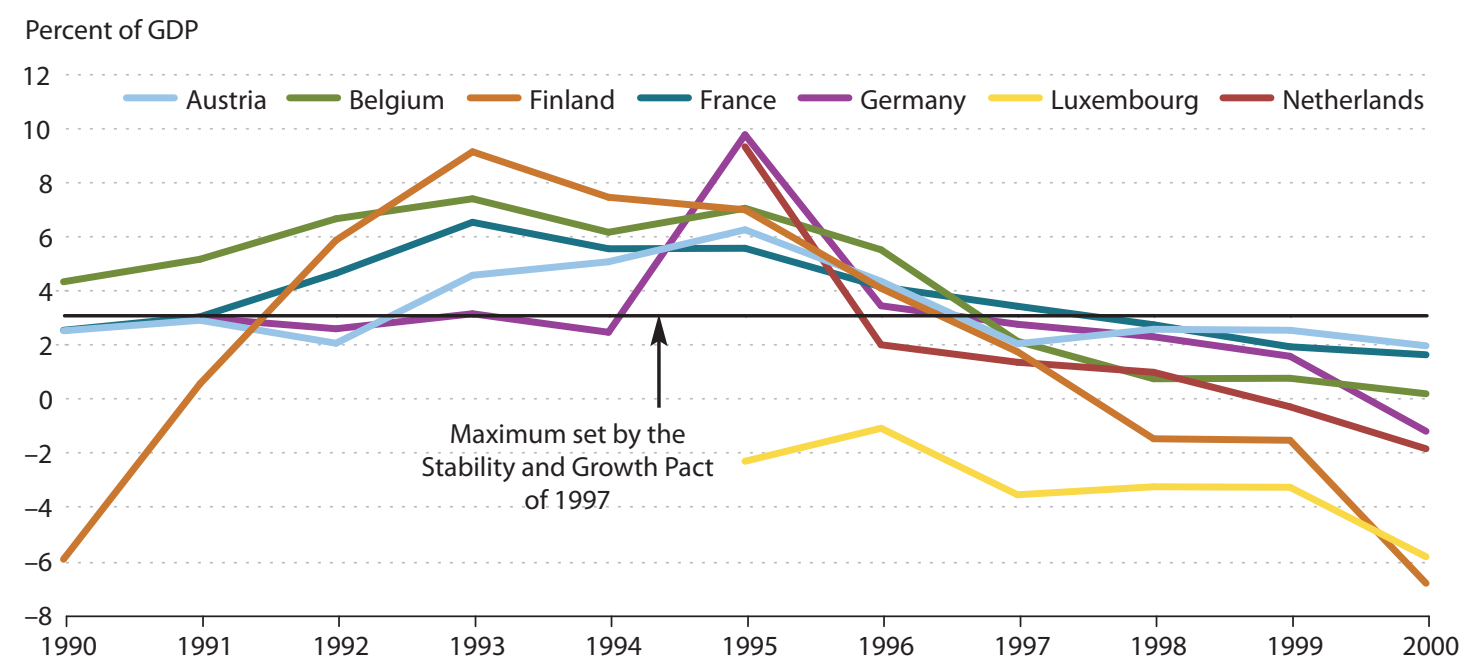

\section{B. Government Deficit-to-GDP Ratio (PIIGS)}

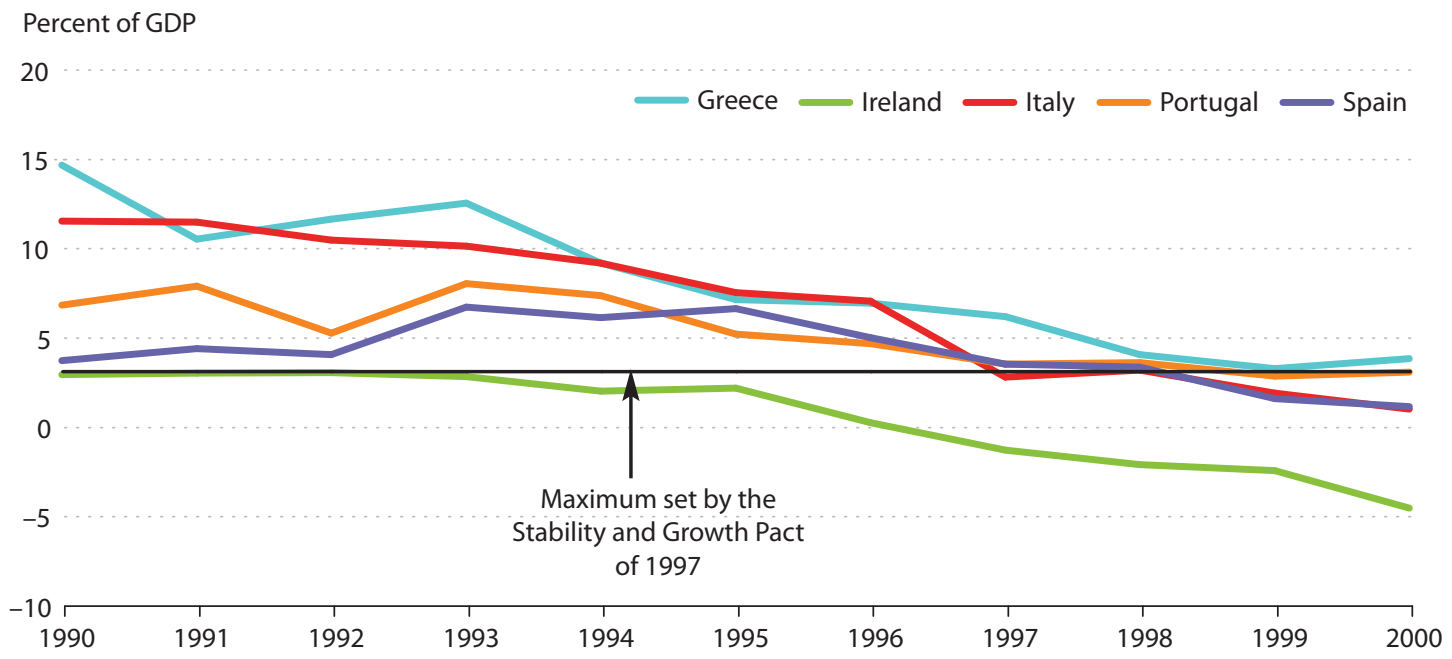

SOURCE: International Monetary Fund, World Economic Outlook Database, April 2012. 


\section{Martin and Waller}

\section{Figure 5}

\section{A. Gross Government Debt-to-GDP Ratio}

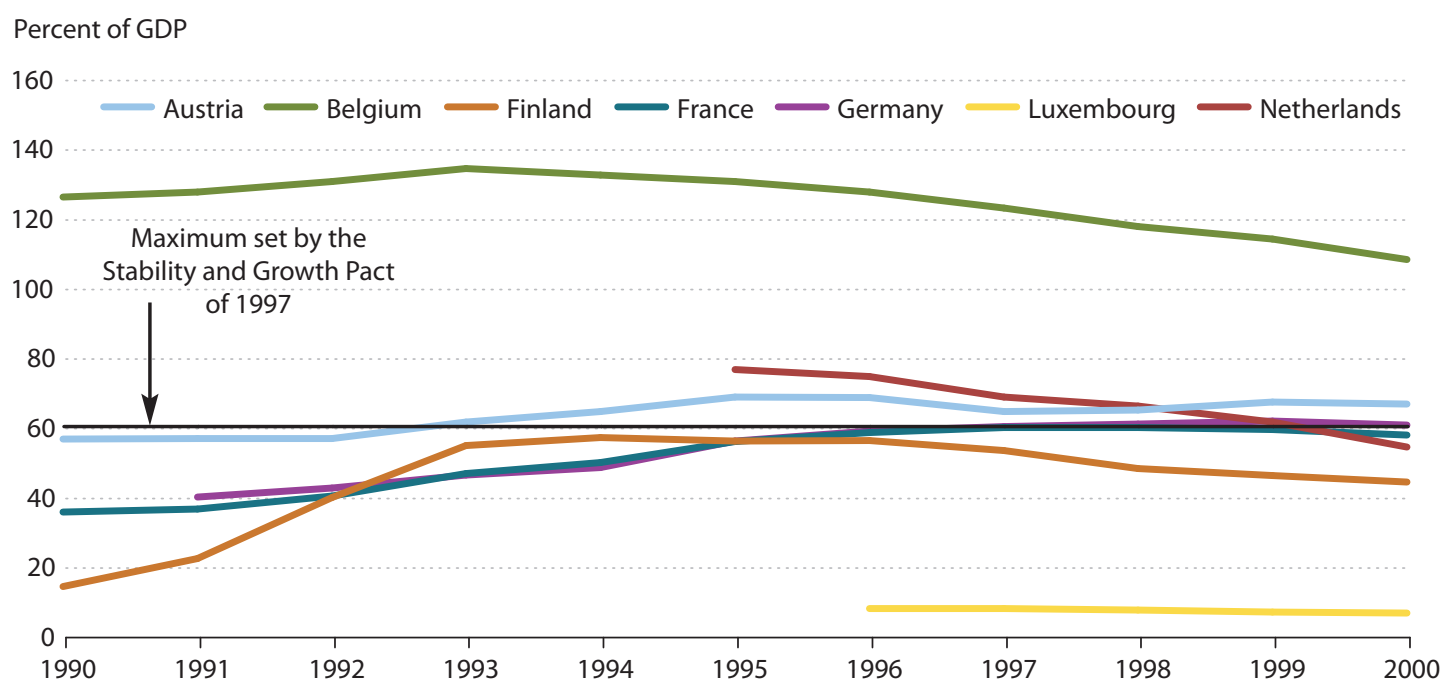

\section{B. Gross Government Debt-to-GDP Ratio (PIIGS)}

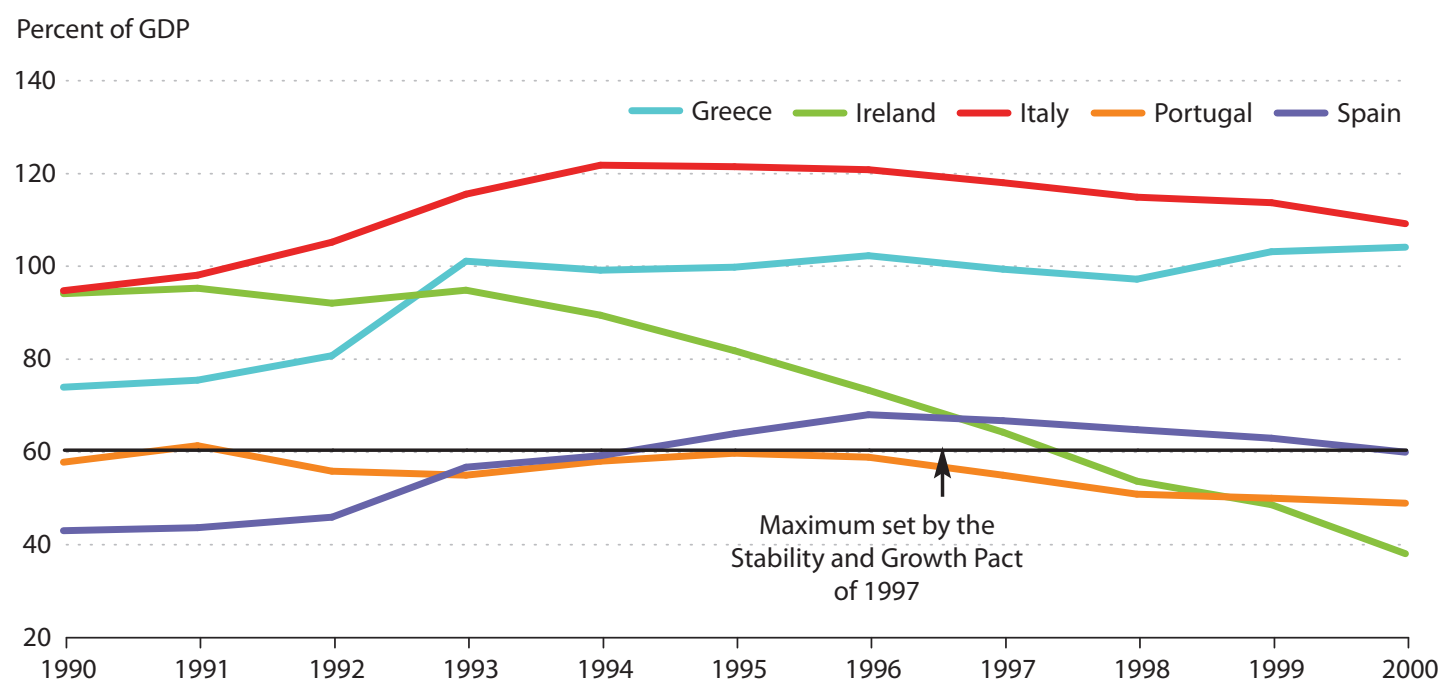

SOURCE: International Monetary Fund, World Economic Outlook Database, April 2012. 
had lowered its debt-to-GDP ratio from 94 percent to 38 percent over the same period. Thus, the general assessment was that, despite failing to meet the criteria in the Stability and Growth Pact, these countries were doing the right thing and would eventually meet the criteria.

What about Greece? As Figure 5B shows, Greece was moving in the wrong direction. Its debt-to-GDP ratio increased from 73 percent in 1990 to 103 percent in 2000. But the euphoria of creating a single currency to compete with the U.S. dollar led to the decision to allow Greece entry into the euro zone.

Upon joining the EMU, the inflation rate in Greece converged to that of the rest of Europe, which is not surprising in a currency union. Somewhat more surprising is that the interest rate on long-term Greek debt converged to the rate paid by Germany and France. The same scenario held true for the debt of Spain, Italy, Ireland, and Portugal.

Thus, financial markets came to view the sovereign debt of euro zone members as being perfect substitutes despite the absence of a fiscal union and the dramatically different fiscal positions of euro members. If the probability of default was the same for each country, then the convergence of inflation rates would justify equivalent interest rates on long-term debt. But given the disparity in fiscal positions, the probability of default was not the same for all countries, and interest rates should have reflected this. The ability to borrow at the same rate of interest as Germany induced some European countries to borrow substantially in international financial markets; notably Portugal's debt-to-GDP ratio increased from 48 percent in 2000 to 72 percent in 2008 .

Again, if investors have confidence that a country will repay its debt, then the rollover problem becomes irrelevant. However, if some type of "shock" occurs that shakes investor confidence, the rollover problem can rear its ugly head and create havoc for governments.

\section{GREECE, IRELAND, AND PORTUGAL}

The fiscal situation in several euro zone countries has deteriorated significantly since 2008 . Figures 6 and 7 show deficit-to-GDP and debt-to-GDP ratios for selected countries.

In the summer of 2009, a new Greek government took power. At the time, Greece was believed to have a deficit-to-GDP ratio of just under 4 percent, while its debt-to-GDP ratio was about 125 percent. After inspecting the tax and spending data, the new government realized that the statistics were flawed: The deficit-to-GDP ratio was not just under 4 percent but rather just under 16 percent! Although everyone suspected the Greeks were misleading the markets with their fiscal numbers, no one thought it was this severe.

At the same time, Ireland was beginning to incur the true cost of bailing out its banking system during the 2007-08 financial crisis. In 2007, Ireland's debt-to-GDP ratio was just 25 percent, and its deficit was zero. By 2010, Ireland's debt-to-GDP ratio was 93 percent, and its deficitto-GDP ratio was over 30 percent. 


\section{Martin and Waller}

\section{Figure 6}

\section{A. Government Deficit-to-GDP Ratio}

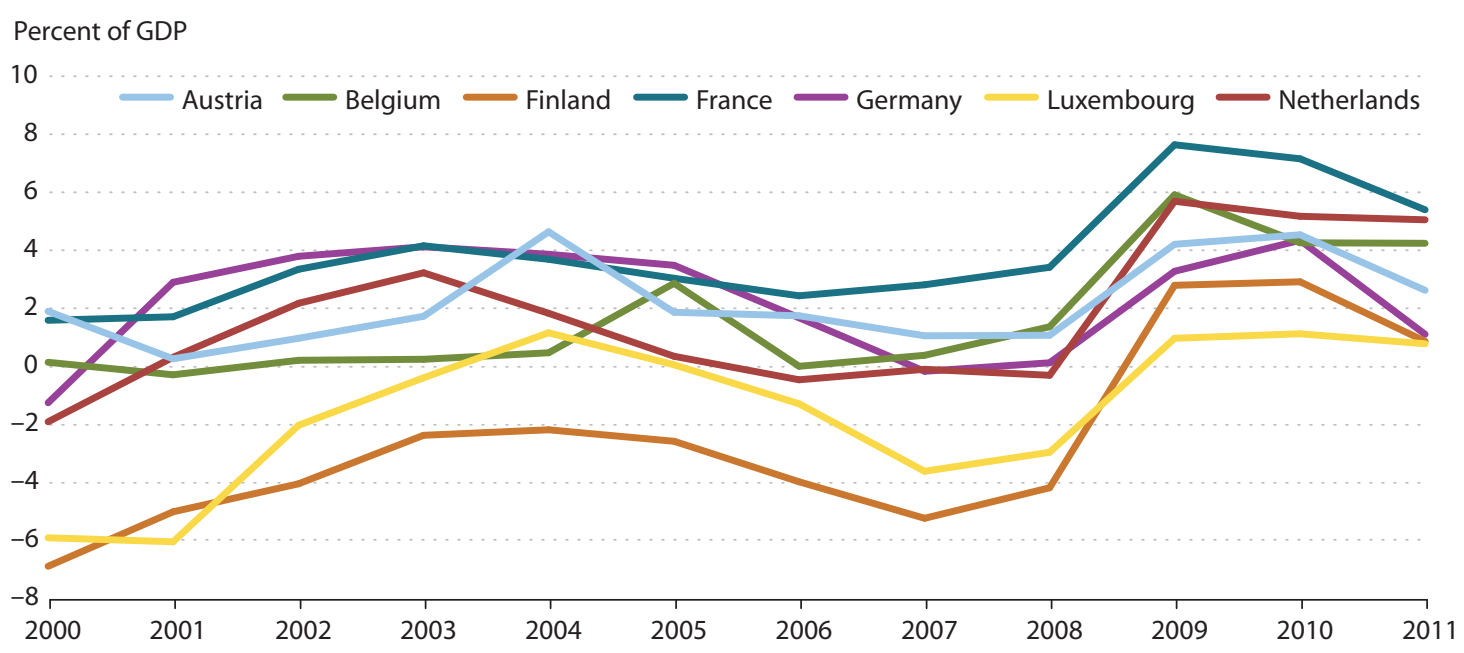

\section{B. Government Deficit-to-GDP Ratio (PIIGS)}

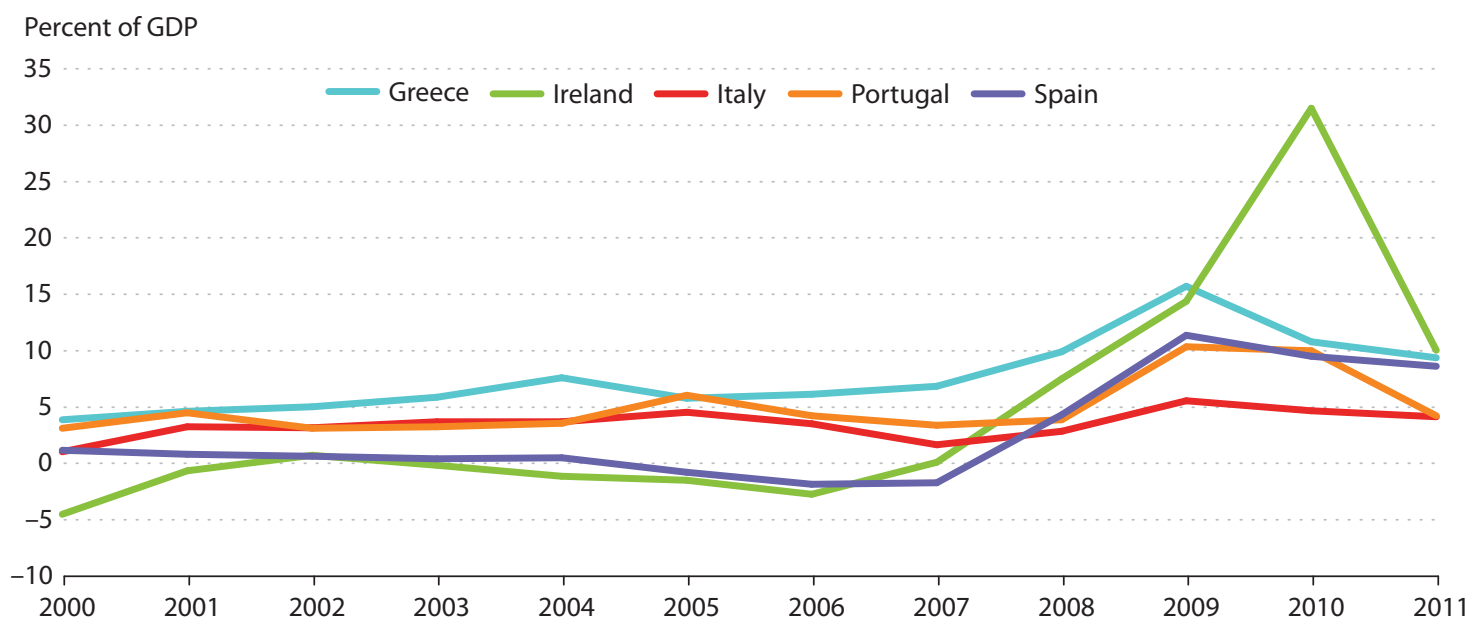

NOTE: The 2011 data for Greece, Portugal, Finland, and France are estimated.

SOURCE: International Monetary Fund, World Economic Outlook Database, April 2012. 


\section{Figure 7}

\section{A. Gross Government Debt-to-GDP Ratio}
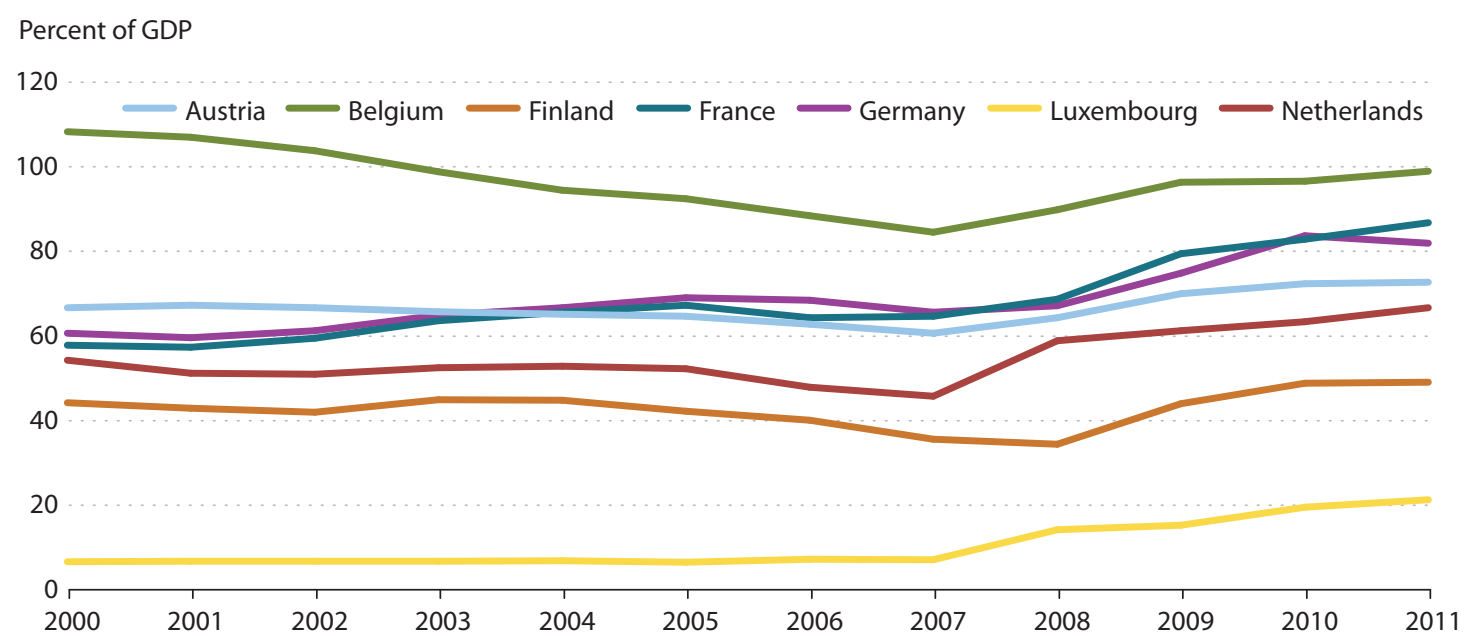

\section{B. Gross Government Debt-to-GDP Ratio (PIIGS)}

Percent of GDP

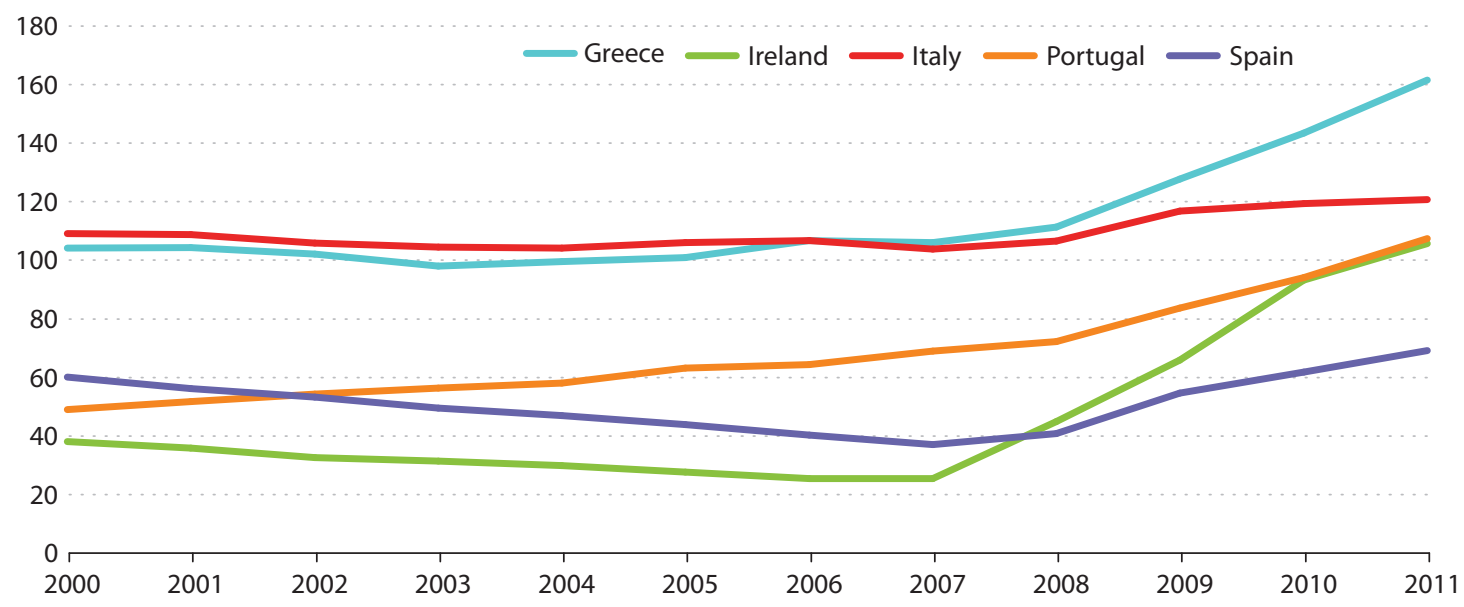

NOTE: The 2011 data for Greece, Portugal, Finland, and France are estimated.

SOURCE: International Monetary Fund, World Economic Outlook Database, April 2012. 


\section{Figure 8}

\section{Yield Spreads between PIIGS' and Germany's 10-Year Bonds}

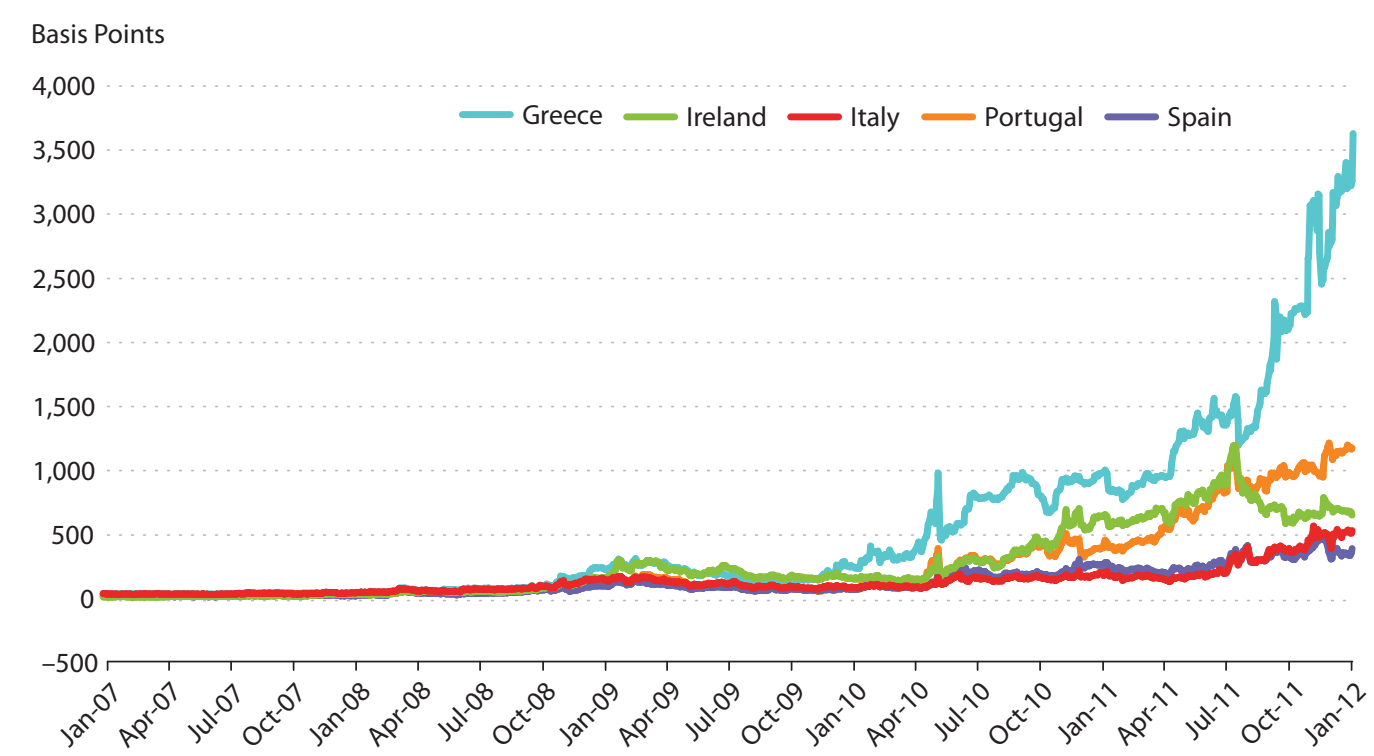

The fiscal shocks hitting these two small countries awakened the financial markets to the risk of default on sovereign debt. No longer did financial markets view the debt of European countries as perfect substitutes for one another. Markets began incorporating default risk into the interest rates charged to various governments to roll over their debt (Figure 8). Between January 2008 and January 2012, the spreads between Greek and German debt increased about 3,300 basis points, while the spread between Irish and German debt jumped to about 550 basis points (peaking at 1,164 basis points in July 2011).

In addition, the change in default risk was reflected in the prices of credit default swaps (CDS) on sovereign debt-essentially an insurance policy against default. If the government defaults on its debt, whoever sells the CDS is responsible for covering the government's debt obligation to the buyer of the CDS. The price demanded by a CDS seller reflects the probability of default-the higher the probability of default, the higher the price charged to acquire the insurance. Figure 9 shows the CDS prices for various European countries; CDS prices skyrocketed for Greece and Ireland (and Portugal, as discussed below), reflecting an increased fear of default.

In response to increasing interest rates, the Greek and Irish governments began discussing or implementing unpopular austerity measures at home to get their fiscal houses in order. Through a combination of tax increases and reduced spending, Greece's deficit-to-GDP ratio fell from 16 percent in 2009 to a projected 8 percent for 2011; Ireland's fell from a peak 31 percent in 2010 to 10 percent in 2011. Although this sounds like good news from the markets' point of view, the severity of the measures also suggested that voters in Greece or Ireland might revolt 


\section{Figure 9}

\section{Credit Default Swap Prices on PIIGS' and Germany's 10-Year Bonds}

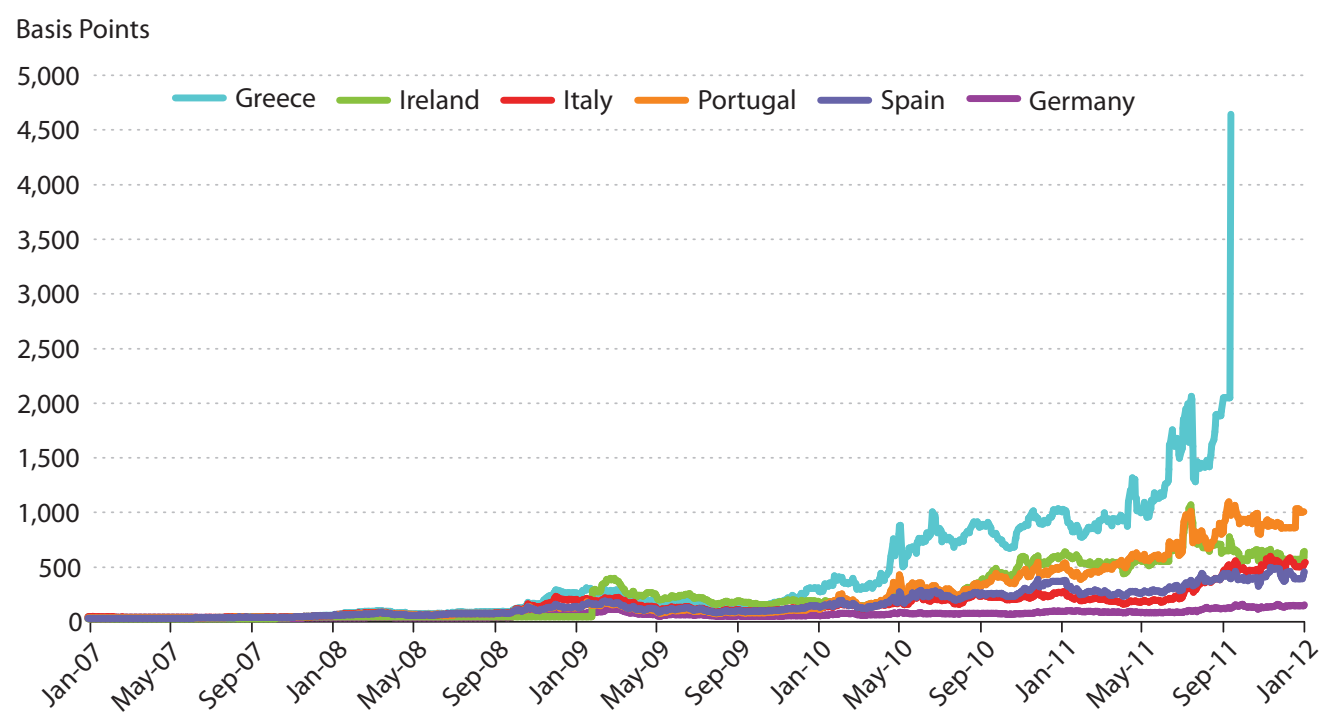

and decide to default rather than bear the costs of austerity. Alas, there is no magic elixir to deal with the burden of debt accumulated over decades.

Portugal is often included when Greece and Ireland are discussed. Although the recent crisis has deteriorated Portugal's economic conditions, its issues are long-standing. For example, the unemployment rate has been rising since 2002-from about 4 percent on average in 2000-01 to 8 percent in 2007. On the fiscal side, the debt-to-GDP ratio increased from 48 percent in 2000 to 68 percent in 2007, with a deficit that averaged about 3 percent of GDP. The financial crisis only made matters worse. In 2009-10, the deficit averaged 10 percent of GDP and the debt-toGDP ratio had climbed to 93 percent. The unemployment rate continued to increase, reaching 12.5 percent in 2011:Q3. GDP contracted in late 2008 and throughout 2009, although growth resumed in 2010, as in most other developed countries. However, output again contracted in the first three quarters of 2011. As with Greece and Ireland, Portugal's government bond yields and CDS prices have increased substantially since early 2010 (see Figures 8 and 9). Between January 2008 and January 2012, the spreads between Portuguese and German debt increased about 1,150 basis points.

\section{THE EU RESPONSE TO THE CRISIS}

Greek banks hold about 20 percent of Greek sovereign debt ( $€ 60$ billion), and a Greek default would dramatically weaken the balance sheets of these banks. Thus, markets stopped rolling over the debt of these banks because of fears they would no longer be able to honor their obligations. This, in turn, meant that Greek banks could not roll over funding of Greek government 


\section{Martin and Waller}

debt. EU leaders, recognizing the gravity of the situation, decided in May 2010 to provide $€ 500$ billion in financing to the member countries facing difficulties rolling over their debt. The biggest contributors to the fund were Germany (€120 billion) and France (€90 billion).

Why would Germany and France be willing to transfer tax revenue from their citizens to Greece and Ireland? One reason is that other European banks also hold a significant amount of Greek and Irish debt. German banks hold 8 percent (about $€ 24$ billion) of Greek debt, and French banks hold about 5 percent ( $€ 15$ billion) of Greek debt. EU leaders feared that a default on Greek and Irish debt would cause a serious deterioration in their own banks' values and that bank runs would ensue.

However, Greece and Ireland are very small economies-Greece's GDP (measured in U.S. dollars) was about $\$ 300$ billion in 2010 , while Ireland's was approximately $\$ 200$ billion. Their combined GDP is less than the GDP of Pennsylvania. It seems hard to believe that a concern over Pennsylvania's state debt would roil world financial markets and frighten U.S. leaders. How could the debt problems of two small countries create so much havoc that the entire EU would intervene? Wouldn't it be easier and cheaper for the German and French governments to just buy the Greek and Irish debt held by their banks?

Greece and Ireland (and Portugal) were not really the problem. They were merely a wake-up call to the very large debt burdens of large European economies, such as Italy and Spain.

Italy has about $€ 1.9$ trillion of debt outstanding, of which 50 percent is held externally. Furthermore, Italy needs to roll over more than $€ 300$ billion of debt in 2012, an amount greater than the entire Greek debt! Complicating matters is the fact that Italy has had essentially zero economic growth over the past decade; thus, it has not been able to reduce its debt burden through income growth. Consequently, Italian debt per capita is the second highest in the world. The debt is particularly burdensome: Italy spends about 5 percent of GDP on interest payments, 2 percentage points more than the euro area average and what the United States pays. Combine this with an aging population and a birth replacement rate of 1.4 , and it is clear why financial markets became alarmed about the possibility of a default on Italian government debt. ${ }^{6}$ As a result, the interest rates on Italian debt soared to 7 percent in late 2011 to induce investors to roll over their holdings of Italian government debt.

Similarly, Spain's public debt has reached about $€ 735$ billion. Roughly a quarter of these obligations are short term (i.e., they mature in less than a year). Spain enjoyed an auspicious run in the first half of the 2000s. Government debt decreased steadily, the product of a growing primary surplus. GDP was growing at an annual rate of 3.6 percent on average before the 2008 crisis hit. Its troubled labor market showed continuous improvement, with the unemployment rate reaching 8 percent in mid-2007, down from 15 percent at the beginning of 2000 .

Since late 2008, Spain's economic conditions have deteriorated substantially. Debt and deficits grew enormously: The deficit averaged 10 percent of GDP in 2009-10, and debt surpassed its 2000 levels, undoing about a decade of steady decline. Output growth has remained tepid, below an annual rate of 1 percent. Most discouraging, the unemployment rate has soared back to a level not seen since the mid-1990s. As of 2011:Q3, the unemployment rate was about 22 percent. As with Italy, interest rates on debt have been increasing steadily since early 2008.

It became clear in 2011 that the initial round of assistance from the EU for sovereign debt funding would not be enough if the markets stopped rolling over the debt of Italy and Spain. Therefore, an additional $€ 340$ billion of funding was provided. 


\section{Figure 10}

\section{U.S. Federal Deficit}

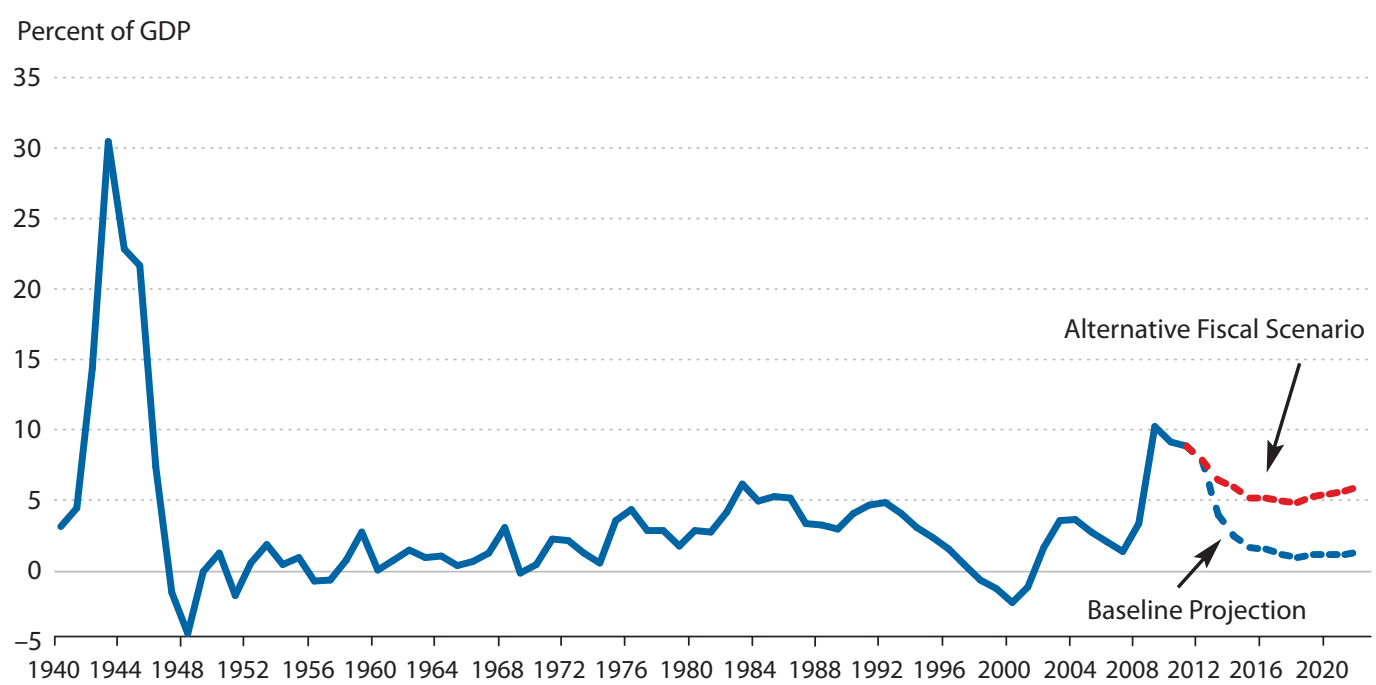

SOURCE: Congressional Budget Office.

In December 2011, the ECB poured liquidity into the banking system to try to stem the crisis. It did so by committing to provide up to $€ 1$ trillion of funding to banks for up to three years. The hope was this action would calm financial markets and ease short-term funding problems for the governments facing rollover pressure. These actions have been very successful to date, as short-term interest rates have declined substantially. However, interest rates beyond three years have not declined much. This suggests the ECB has given European governments three years of breathing room to make the appropriate fiscal adjustments. Nevertheless, the adjustments must be made. Only time will tell whether these actions will be sufficient to finally end the sovereign debt crisis in Europe.

On March 9, 2012, four-fifths of Greece's private creditors agreed to a bond swap. This debt restructuring will reduce obligations by $€ 100$ billion, about half the face value of eligible bonds. Given that some creditors will be forced to exchange their bond holdings, this event has triggered the payment of CDS on Greek debt. The default will impose severe losses on domestic banks, which, as mentioned above, hold a substantial fraction of Greek debt.

\section{THE SITUATION IN THE UNITED STATES}

As the economic situation in Europe has deteriorated, the United States has been going down its own rocky path. In response to the recession following the recent financial crisis, the U.S. government has been running deficits of a magnitude not seen since World War II (Figure 10). These deficits are the result of both lower revenue and higher expenditure, the latter mostly due to increases in income security programs (e.g., unemployment benefits) and Social Security, 


\section{Martin and Waller}

Medicare, and Medicaid payments. As a consequence, total debt from all levels of government increased from 53 percent of GDP in 2007 to 84 percent in 2011.

Despite the large increase in debt, U.S. bond yields have remained low (about zero for 3-month and 1-year bonds) throughout this episode. In part, the reason is "flight to quality": As investors have reduced their exposure to troubled private asset markets (e.g., mortgages) and risky sovereign debt (e.g., Greece, Ireland, and Portugal, but also Italy and Spain), the demand for U.S. Treasury securities has soared. Germany, Japan, and the United Kingdom have also experienced a decline in government bond yields due to increased demand.

Regardless of how the European situation gets resolved, the United States faces its own challenges. According to the March 2012 baseline projections from the Congressional Budget Office (CBO), federal debt held by the public will increase from 68 percent of GDP in 2011 to 71 percent of GDP in 2016, reaching a peak of 76 percent of GDP in 2013. Interest payments on the debt will increase from 1.5 percent to 1.8 percent of GDP over the same period. Under an alternative fiscal scenario-which mostly assumes the extension of expiring tax provisions-the CBO projects that debt held by the public would rise to 83 percent of GDP by 2016 .

No matter which budget outlook prevails, the United States will have to decide whether it is comfortable maintaining a larger stock of debt, with its associated higher financial burden, or prefers to return to levels that are more normal by historic standards. Either way, there will be a need for higher taxation and stronger incentives for inflation. The $\mathrm{CBO}$ currently estimates that federal tax revenue will increase by about 5 percentage points of GDP between 2011 and 2016 if current tax legislation is carried out. $\cdot$ Under the alternative fiscal scenario, this increase would be cut in half.

Compounding this situation is the outlook for expenditures. Since the 1950s, transfersSocial Security, Medicare, Medicaid, and so on-have been steadily growing as a share of federal outlays. Currently, transfers represent about two-thirds of expenditures net of interest payments; by comparison, defense spending is about a fifth of all expenditures. By 2016, transfers are projected to be at 14 percent of GDP, and total outlays before interest payments will reach 23 percent of GDP.

In summary, the United States faces difficult fiscal choices. Taxes must be raised and/or spending must be cut. The pain associated with these actions will fall on different groups, and that leads to political conflict. Political conflict means delay in getting the U.S. fiscal situation on firmer ground. Whether this conflict will scare financial markets and lead to a rollover crisis for the United States remains to be seen.

\section{CONCLUSION}

So what is the moral of this modern debt tragedy? As is the case with any form of debt, the ability to borrow from the future to finance current consumption can be tremendously beneficial. For example, the U.S. debt incurred to finance World War II helped free the world from fascism and Nazism, thereby setting the stage for the spread of democracy around the world. Most would agree that borrowing in this instance generated large benefits for the entire world. Therefore, public debt can be used to achieve good outcomes for society.

However, the tragedy of this story is that borrowing, by its very nature, is seductive-the rewards are felt immediately and the pain is postponed to the future. Thus, it is very tempting 
for government leaders, much like individuals and households, to push the envelope of borrowing to obtain current pleasure while downplaying the pain that will come. As a result, debt burdens can rise to levels that eventually become unsustainable, leading to crisis and periods of severe austerity. The world has moved into such an era now, and the final act of this modern tragedy is yet to come.

\section{NOTES}

1 This figure corresponds to what is known as "debt held by the public." The U.S. "gross debt," which includes holdings by federal agencies - that is, money that the government owes to itself-was about $\$ 15$ trillion by the end of fiscal year 2011.

2 Since the United States is a democracy that chooses its government representatives from its own citizenry, we refer to the debt accumulated by the government as the "national debt" or "the debt of the nation." In the past, when monarchies were the main form of government, the debt was referred to as "sovereign debt" since it was debt accumulated by the monarchy as opposed to the nation's citizens. Today, the terms "national debt," "government debt," and "sovereign debt" are all conceptually the same and are used interchangeably.

$\underline{3}$ Note that default on sovereign debt is rarely full and absolute. Generally, payments are suspended for a while (it can be a very long while) and restructuring takes place. This process typically involves both a reduction in total commitments and a rescheduling of payments.

4 This was the reason given by Standard \& Poor's for downgrading U.S. debt in August 2011.

5 We use definitions consistent with the Maastricht treaty. Thus, fiscal accounts cover all levels of government-that is, central, local, and social security programs. "Debt" is defined as "gross debt," which includes currency and deposits, securities (i.e., bonds), and loans.

6 The "replacement rate" is the number of children born to each woman in a country. Ignoring immigration, a country's population will shrink if the replacement rate is less than 2 for an extended period of time. A shrinking population means a smaller future pool of workers to tax and thereby fund government programs.

$\underline{7}$ This is mainly due to the expiration of tax provisions enacted in 2001, 2003, and 2009 and extended in 2010.

\section{REFERENCES}

Barro, Robert J. “On the Determination of the Public Debt." Journal of Political Economy, October 1979, 87(5), pp. 940-71.

Ohanian, Lee E. The Macroeconomic Effects of War Finance in the United States: Taxes, Inflation, and Deficit Finance. New York, Garland Press, 1998.

Reinhart, Carmen M. and Rogoff, Kenneth S. This Time Is Different: Eight Centuries of Financial Folly. Princeton, NJ: Princeton University Press, 2009. 


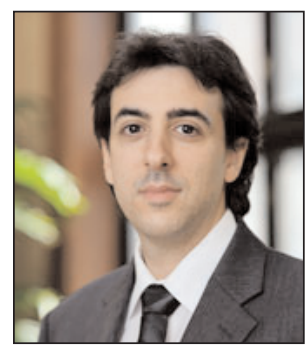

\section{Fernando M. Martin}

Senior economist, Federal Reserve Bank of St. Louis

http://research.stlouisfed.org/econ/martin/

\section{Research Focus}

Fernando Martin's areas of interest are macroeconomics, monetary theory, public finance, and dynamic contracts.

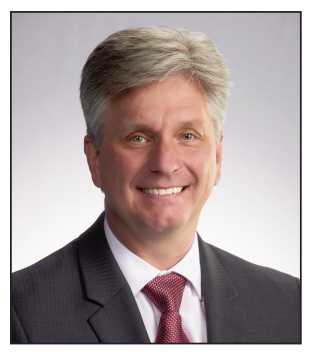

\section{Christopher J. Waller}

Senior vice president and director of research, Federal Reserve Bank of St. Louis

http://research.stlouisfed.org/econ/waller/

\section{Research Focus}

Chris Waller's areas of interest are monetary theory, political economy, and macroeconomic theory. 